across the Plain of York to the Humber gorge. That is, the hard Oolites and Chalk of the York wolds on the north and of the Lincoln heights and Lincolnshire wolds on the south, have formed the gorge of the Humber, which once flowed as high and higher than these heights. In the meantime rain and the rivers have always excavated deep flat valleys in the soft Triassic strata west of these heights and have deposited patches of alluviums in them ever varying in height with the ever varying level of the bed of the Humber gorge. Now that the Humber gorge is cut down to the level of the sea, these alluviums (like all alluviums next the sea or deltas) will constantly rise from overflow and deposit, except where they are embanked.

G. G.

\title{
MARKS OF SEA-ACTION ON THE CLIFFS, GORGES, AND VALLEYS OF WALES.
}

\section{To the Editor of the Grologicar Magazine.}

SrR,-Having not long since explored a considerable portion of the country described by Mr. Mackintosh, in his interesting paper on the "Cliffs and Valleys of Wales," chiefly with a view to studying the physical geology of the district, I venture to ask space for a few thoughts on "the great denudation puzzle." Admitting the facts brought forward by my friend Mr. Maw, in his admirable remarks on "Watersheds," and the general soundness of his arguments, might we not still expect to find marks of marine-action in the formation of beaches, the erosion of cliffs, etc., in precisely those situations in which Mr. Mackintosh claims to have found them? And can such marks be considered, then, as any real evidence against the subaërial theory of denudation? These are the questions I propose very briefly to consider.

Granting that the Eglwyseg cliffs, for, example, do bear marks of having, at one time, been washed by the waves as those of Llandudno are now-if we mark the elevation of the supposed beach line at their base, and trace out the line of such elevation on a contour map of North and South Wales, shall we not get just such an intricate outline of land and water, such a series of small islands, and landlocked inlets, as Mr. Maw has shown to be found in the case where a tract of land, with its recent configuration of hill and dale, is known to have been suddenly submerged within historic times, but which can not be found anywhere in the world where the sea washes the coast of land long raised to any considerable height above its level ? There was, beyond doubt, a period when the waters of the Glacial sea covered the low lands of Cheshire, Flint, Denbigh, and North Shropshire; while such elevations as Wenlock Edge, the Longmynd, Caradoc, and Wrekin-Cyru-y-Brain, and Eglwyseg rocks were above water, as well as the higher peaks. (Mr. Maw has himself shown this in the case of Wenlock Edge, in his paper on the "Severn Valley Drift," in the Quarterly Journal of the Geological Society for May, 1864.) And we may reasonably look to find traces here and there at the bases of those high lands of the action of the 
sea. Supposing, then, the general contour of the land to have been in the main, what it now is, previous to that submergence, are not almost all the phenomena described by Mr. Mackintosh precisely such as we might expect to have been produced by such a subsidence as would permit the sea to flow into the existing valleys of Wales? Are not the traces ${ }^{1}$ of sea-action, which he finds, more consistent, in short, with the theory of a temporary submergence of land already modelled into nearly its present contour, than with that of the eating out of such an intricate network of "fiords" by the gradual operation of the sea upon an elevated and rocky land? How, again, I would ask, can Mr. Mackintosh possibly explain the formation of such a long tortuous gorge as that, for example, through which the river Alyn flows for some miles above Gresford? Taking that gorge in connexion with the ridge of Drift-gravel, at the east of Gresford and Wrexham (the old sea beach, perhaps,) through which the river cuts its way, we have as clear a case as may be of river-action. And if there, why not in other similar gorges throughout the country? Even Mr. Mackintosh will scarcely argue that the long alternations of tunnel and deep cutting, through which so many of the limestone rivers of Yorkshire find their way, were made for them by the sea. I am, Sir, yours faithfully,

Stottesden Vicarage, Bewdiey.

\section{Wrlliam Purton.}

\section{To the Editor of the Geological Magazine.}

Str,-Mr. Hull's letter on the "River-denudation of Valleys," in your number for October, is valuable as again calling attention to a very puzzling fact, which I agree with him in thinking has not yet received a perfectly satisfactory explanation. I pointed out some time ago two cases in North Staffordshire of a valley crossed by a watershed, exactly like the instances described by Mr. Hull, but on a larger scale. ${ }^{2}$

It is not, however, my intention to attempt a solution of this knotty problem, but to point out one sentence in Mr. Hull's letter, so plausible, and, at the same time, so illogical, savouring of the post hoc ergo propter hoc, that I hope the author will excuse me if I show the flaw in his reasoning.

The sentence is, "It is less incredible (to say the least of it) to assume the agency of the sea in the formation of these valleys (or parts of them), which we know was there, than that of a stream of which there is no trace."

The argument stated formally runs thus :

We know that the sea has been over the ground now occupied by the vale of Todmorden.

1 Except, indeed, his supposed instances of "sea-worn summits of hills," about which I confess I am rather sceptical.

2 See the Memoir of the Geological Survey on the country round Stockport, Macclesfield, Congleton, and Leek (p. 13). 